\title{
Factors of Formation and Features of Physical and Chemical Characteristics of the Bottom Sediments in the Balaklava Bay (the Black Sea)
}

\author{
K.I. Gurov, E.I. Ovsyany, E.A. Kotelyanets, S.K. Konovalov \\ Marine Hydrophysical Institute, Russian Academy of Sciences, Sevastopol, \\ Russian Federation \\ E-mail:gurovki@gmail.com
}

\begin{abstract}
The physicochemical characteristics of the sediments of Balaklava bay: granulometric composition and fractional composition content of organic and inorganic carbon are considered. The spatial distribution of the main factions of particle size distribution and content of organic carbon (TOC) and calcium carbonate $\left(\mathrm{CaCO}_{3}\right)$ are investigated. The relationship between the organic and inorganic carbon and particle size distribution of sediments are analyzed. The main formation factors of the sediments from Balaklava bay are hightlighted. The results of the performed investigations have shown that the bottom deposits in the Balaklava Bay are represented mainly by silts and in some areas the gravel and sandy materials are interspersed. On average, for all the stations the fine-dispersed fraction content makes up 61\%. The coarse-dispersed material is concentrated near the coast, and at the bay exit; the increased content of the sand fraction is typical for the central part of the water area. The calcium carbonate content in the Balaklava Bay varies within 18.32-82.95 \%; its average value constitutes $40.06 \%$. Its maximum concentrations are in the coastal parts of the bay. The highest correlation between the inorganic carbon content and the granulometric composition in the samples is observed in the coarse-dispersed material (fraction $2-1 \mathrm{~mm}$ ). As for the fine-dispersed material, the sandy and alevrite-pelite silts are characterized by the inverse relation: from 0.4 - for the fraction $0.25-0.1 \mathrm{~mm}$ up to 0.6 for the fraction lower than $0.05 \mathrm{~mm}$. The organic carbon content varies from 0.66 to $4.74 \%$; the average value is $2.37 \%$. The presence of the increased values in the central part of the bay can be explained by "weak" water exchange formed by minimum wind and wave effect and insignificant eddy formations.
\end{abstract}

Keywords: Balaklava Bay, bottom sediments, granulometric composition, fractional composition, organic carbon, inorganic carbon.

DOI: $10.22449 / 1573-160 X-2015-4-46-52$

(C) 2015, K.I. Gurov, E.I. Ovsyany, E.A. Kotelyanets, S.K. Konovalov

(C) 2015, Physical Oceanography

Introduction. Coastal areas have always been an object of active human activity. It has contributed to formation of specific ecosystems which now constitute a part of the total ecosystem of the Black Sea. Study of sediments, their physical and chemical features, as well as the processes taking place in the water - suspended matter - sediments system is an important part of the total system of the coastal waters monitoring.

A distinctive feature of the bottom sediments of the Black Sea coastal area is a high rate of sedimentation. In contrast to the deep-sea part where the sedimentation rate is $0.15-0.35 \mathrm{~mm} /$ year [1], this process in the coastal areas increases. According to [2] in the Crimea coastal regions where the determining factor is the abrasion processes, the sedimentation rate is $0.35 \mathrm{~mm} / \mathrm{year}$, in the Sevastopol Bay $2.4 \mathrm{~mm} /$ year and in the Danube estuarine zone $-11.5 \mathrm{~mm} /$ year [3]. 
Among the important factors of sediment formation we can distinguish the depth of the area under study, the distance from the coast and the form of the bottom relief. Hydrodynamic features of the water area and vital activity of the living organisms can also be attributed to the basic factors of sedimentation [4].

The main characteristics of bottom sediments are the organic matter content and the granulometric composition and humidity. Significance of these features is defined by their influence upon the processes of absorption, retention and accumulation of pollutants. Study of organic $\left(\mathrm{C}_{\mathrm{opr}}\right)$ and inorganic $\left(\mathrm{CaCO}_{3}\right)$ carbon implies an important point, i.e. analysis of its spatial distribution and close relations with the sediment fractional composition.

Investigation of bottom sediments provides the data that can be widely used in practice. The information on the bottom sediment granulometric and fractional composition is applied in geological researches [5] and in analyzing the features of trace metals' distribution [6]. Such physical parameters as sediment density and particles' average diameter are used to study the processes of sediment transport in the coastal regions [7]. Analysis of $\mathrm{C}_{\text {opr }}$ and $\mathrm{CaCO}_{3}$ content plays an important role in studying the components of the carbonate system and the carbon cycle [8].

The present paper examines bottom sediments in the Balaklava Bay. In contrast to hydrological, hydrochemical and hydrobiologicl studies [9 - 16], the bottom sediments in the bay were paid inconvenient attention in the scientific literature $[6,17]$. The purpose of this paper is to study the sediment physical and chemical characteristics (granulometric and fractional composition, content of $\mathrm{C}_{\text {opr }}$ and $\mathrm{CaCO}_{3}$ ), the distinguishing features of its spatial distribution in the bay water area and the correlations between these characteristics and the factors of their formation.

Materials and methods of investigation. The samples taken in the bottom sediment surface layer $(0-5 \mathrm{~cm})$ of the Balaklava Bay in 2005 were investigated in the present paper. Location of sampling stations is shown in Fig. 1. The applied scheme of stations allows conditional zoning of the water area directed from the north to the south.

In the northern (internal and the most shallow) part stations 1, 2, 4, 5, 6 are located, in the central part - stations $7-11$. Further, in the narrowest part of the Balaklava Bay stations $12-14$ are situated, and stations 16 and 17 are in the southern part and at the bay exit.

Sediment samples were taken using a bottom sampler (0.025) according to State Standard 17.1.5.01-80 [18]. The combined sieve analysis (decantation and dispersion method) was used to determine the granulometric composition [19]. The inorganic carbon content (carbonate content) in a sample was found by the weightvolume method after the carbonates were decomposed by hydrochloric acid [20]. The organic carbon concentration in a sample was determined by the spectrophotometry method after oxidation of organic matter by the chromic-sulfuric mixture [21]. 

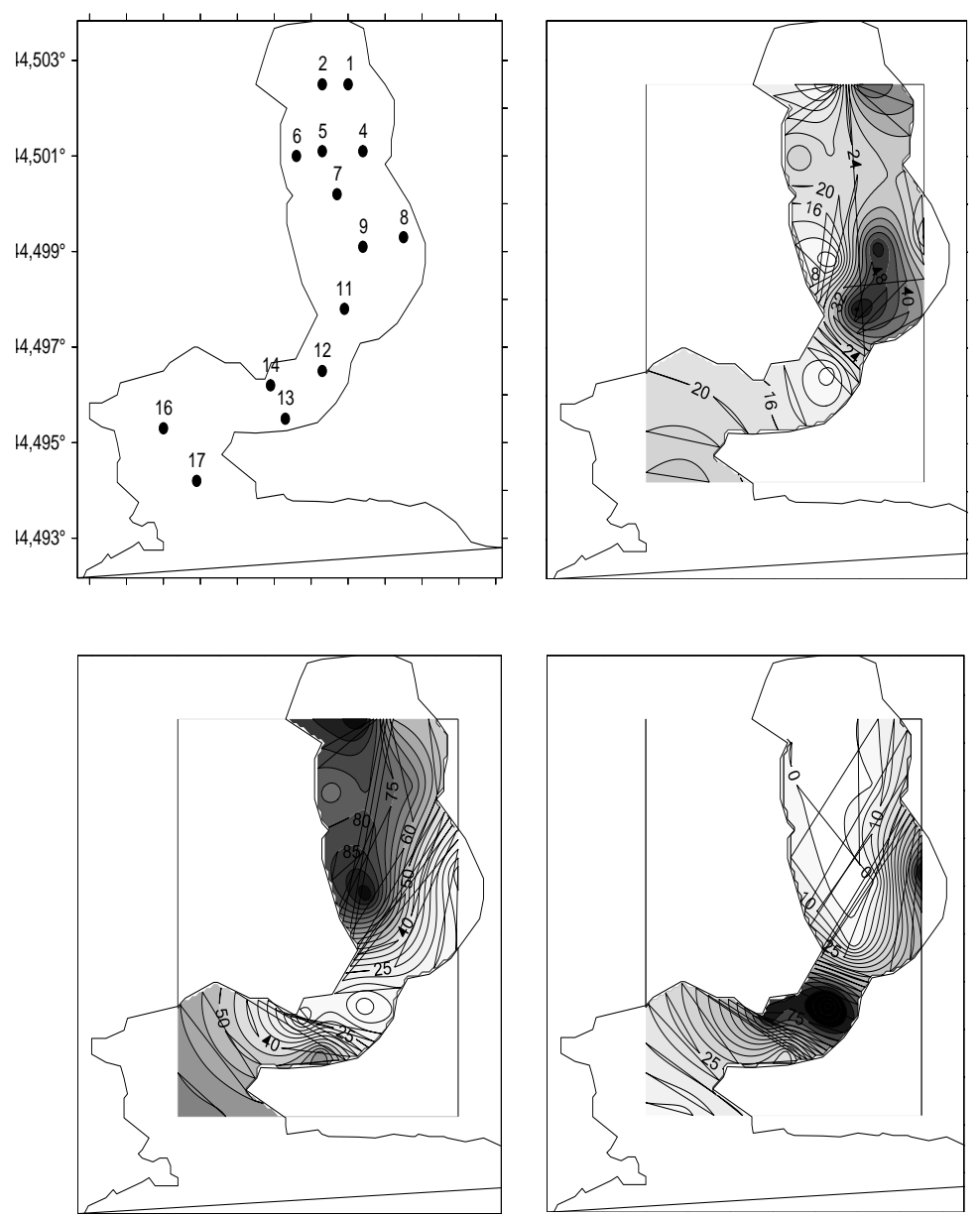

Fig. 1. Spatial distribution of the stations in the Balaklava Bay in 2005 where the following samples of the bottom sediment surface layer $(0-5 \mathrm{~cm})$ were taken: bottom sediment $(a)$ and the granulometric composition fractions, i.e. sand $(b)$, silt $(c)$ and gravel $(d)$

Results and discussion. The Balaklava Bay is a residue of the rias coast located within the Megalo-Yalo Gulf and represents a semi-enclosed water area with the width up to $200 \mathrm{~m}$ and the depth up to $30 \mathrm{~m}[9,10]$.

The coastline length is $3.33 \mathrm{~km}$, the bay average depth is $12.5 \mathrm{~m}$ and the depth of $47 \%$ of the water area varies from 4 to $12 \mathrm{~m}$ [10]. Bathymetry and orography of the bay have changed significantly since late XIX to the beginning of the XXI century. The most considerable changes took place in the northern shallow part where deepening of the bay resulted in the depth increase from $1.83 \mathrm{~m}$ to $4-5 \mathrm{~m}$. Besides, the original circular form of the bay internal part has transformed with time into a rectangular one. The coastline configuration and bottom topography to a great extent determine the features of bottom sediments in the bay. Due to their geological structure the coasts of the Balaklava Bay and the surrounding MegaloYalo Gulf prevent development of the abrasion processes [11]. 
The processes of formation and redistribution of bottom sediments in the coastal areas are significantly affected by the wind and wave impact. It is noted in [11] that the Balaklava Bay has its proper distinctive features of the wind and wave modes. Except for its narrow twisting part, the wind direction in the bay coincides with the axial line. Due to the orography of the surrounding region, the bay water area is protected from the impact of the western and eastern winds. In the southern open part of the bay storm waves are possible. In the central and northern (shallower) parts the wind and wave impact is minimized [12].

As for the structure of surface currents, it is represented in [11] by three variants. Being influenced by the northerly winds, the south-directed current occurs and intensifies in the narrow part of the bay owing to the tunnel effect. When the wind is south the currents' northern vectors are formed the velocity of which increases in the northeastern part of the water area. When the impact of the eastern and western winds is weak, as well as at calm weather, the vortex formations of cyclonic and anticyclonic directions take place.

The structure of the bottom currents is described in [13]. It was shown that benthic circulation was weak. The direction of bottom currents is opposite to that of the surface ones. The flow is formed in the internal part and propagates to the south along the western coast.

Among the factors producing the strongest influence on the ecological state of the Balaklava Bay, distinguished are human activity and water dynamics, namely, the surge process. [14] Within the bay water area its two parts are the most contaminated [11]. The first one is the internal shallow part. Rain drainage from the river Balaklavka and local sources of anthropogenic pollution in the coastal zone [6] together with weak water exchange [15] contributed to accumulation of suspended matter and dissolved organics.

The other area subjected to pollution is located in the bay southern part close to the collector discharging $\sim 3$ million $\mathrm{m}^{3}$ /year of wastewater. This area is characterized by the increased concentrations of dissolved substances, suspended matter and mineral oil [16].

It is shown in [17] that the deposits represented by a fine-dispersed fraction in the upper part of the bay are replaced by silt sands in the central part, and in the narrowest part and at the bay exit - by shell detritus with the inclusions, first, of sand and fine gravel, and then - of silt.

In the sediment core samples taken in 2005 a similar scheme of changing the fraction structure is observed (Fig. 1). At the same time the obtained results permit to detail the scheme and to define quantitative characteristics.

The major part of the samples is presented by alevrite-pelite and sandy silts. The coarse-dispersed material is concentrated at four stations located close to the coast.

The alevrite-pelite silts are predominant in the bottom sediments of the northern and northwestern internal parts of the bay. Here the content of fine-dispersed fractions achieves its maximum values (71.47 - 99.95\%). The total content of the silt fraction in the bay sediments varies from $1.3-99.95 \%$, and the average value for all the samples constitutes $58.20 \%$. The characteristic distribution of the silt fraction in these parts of the bay is governed by influence of the natural slope runoff and also by that of industrial and utility companies. The increased content of silt material at the bay exit (station 16) is due to the bottom relief features, namely, the depth increase [10]. 
Moving to the central part the fine-dispersed silts are replaced by the sandy ones. The sediment fractional composition at certain stations (stations $1,9,11)$ reflects the ratio of the silt fraction to the sand ones as $1: 1$. The maximum content of the sand material is $56-57 \%$ and the average value for all the samples is $23.08 \%$. In addition to the central part, the sandy silts are concentrated in the deposits of the north-eastern part of the bay.

It was mentioned above that the gravel fraction is most substantial at four stations (stations $8,12,13,16$ ) where its values vary within $11.79-98.9 \%$. At other stations the coarse-dispersed material is weakly represented, its values vary in the range $0.03-0.26 \%$. Propagation of the gravel fractions from the north-east to the south-west in a form of local maximums in the coastal area and at the bay exit is conditioned by the increased content of the shell gravel and detritus in these areas.

Due to the effect of morphological and hydrological features and also in connection with close proximity of anthropogenic sources of pollution, the northern and the north-eastern shallow-water parts of the bay are the most interesting for investigation.

The organic carbon and carbonate contents are among the important sedimentforming and ecological factors [22]. Spatial distribution of the $\mathrm{CaCO}_{3}$ and $\mathrm{C}_{\mathrm{opr}}$ contents in the bottom sediments is shown in Fig. 2.
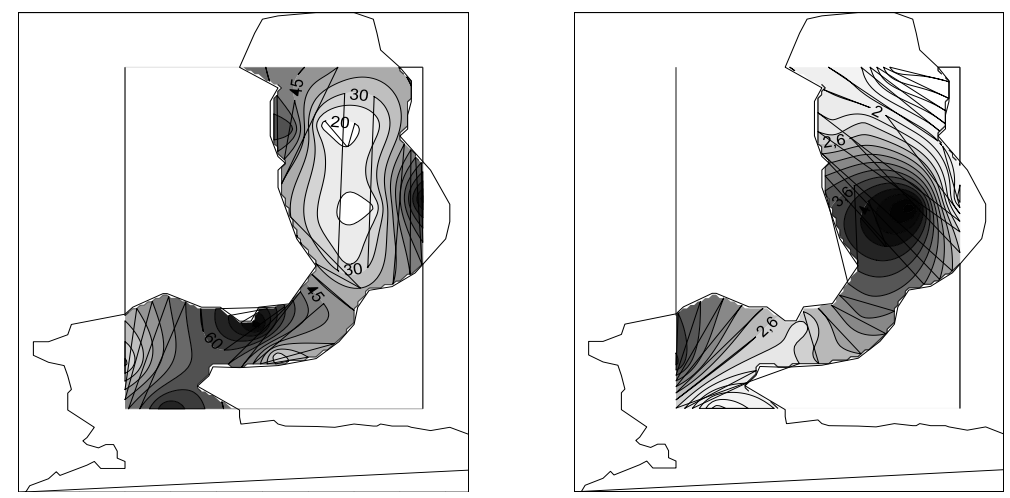

Fig. 2. Distribution of $\mathrm{CaCO}_{3}(a)$ and $\mathbf{C}_{\text {opr }}(b)$ in the surface layer $(0-5 \mathrm{~cm})$ of bottom sediments in the Balaklava Bay in 2005

The calcium carbonate content in the Balaklava Bay varies within 18.32 $82.95 \%$; its average value constitutes $40.06 \%$. Its maximum concentrations are in the coastal parts of the bay. The highest correlation between the inorganic carbon content and the granulometric composition (0.8) in the samples is observed in the coarse-dispersed material (fraction $2-1 \mathrm{~mm}$ ). As for the fine-dispersed material, the sandy and alevrite-pelite silts are characterized by the inverse relation: from 0.4 - for the fraction $0.25-0.1 \mathrm{~mm}$ up to 0.6 for the fraction lower than $0.05 \mathrm{~mm}$.

The organic carbon content varies from 0.66 to $4.74 \%$; the average value is $2.37 \%$. Location of the areas with the highest $\mathrm{C}_{\text {opr }}$ concentrations is conditioned by the described-above hydro-meteorological and circulation features of the bay. Presence of its increased values in the central part is explained by a weak water exchange conditioned by a minimal wind and wave impact and insignificant vortex formations. At the bay exit the near-bottom circulation is hampered due to the depth drop from 10 to $20 \mathrm{~m}$. 
Conclusions. The paper examines important physical (granulometric and fractional composition) and chemical (content of organic and inorganic carbon) characteristics of the bottom sediments. Formation of the sediment fractional composition is conditioned both by morphometric and orographic features of the bay and the circulation processes taking place in it. The results of the performed investigations have shown that the bottom deposits in the Balaklava Bay are represented mainly by silts and in some areas the gravel and sandy materials are interspersed. On the whole, for all the stations the fine-dispersed fraction content constitutes $58.20 \%$. The coarse-dispersed material is concentrated near the coast, and at the bay exit; the increased content of the sand fraction is typical for the central part of the water area.

The obtained results testify to the fact that, in contrast to the existing scientific literature data, distribution of the bottom sediment fractions in the northern shallow part of the bay has changed insignificantly. These changes took place due to increase of depth and change of the bay coastline contour. In course of the previous century general features of the sediment distribution spatial structure have remained the same.

The organic carbon maximum concentrations in the bottom sediment surface layer $(0-5 \mathrm{~cm})$ are concentrated around the maximum depths and in the areas with the increased content of fine-dispersed silts.

The values of carbonate content increase from the bay center to its coastal areas; and the maximum values are observed in the samples with the increased shell and shell detritus content.

\section{REFERENCES}

1. Arkhangelskiy, A.D., 1927, "Ob osadkakh Chernogo morya [On precipitations of the Black Sea]”, vol. 5, no. 3-4, pp. 199-289 (in Russian).

2. Denisov, V.I., 1998, "Zakonomernosti obrazovaniya vzveshennogo materiala na shelfe Chernogo morya [Regularities of suspended matter formation on the Black Sea shelf]", Avtoreferat dissertatsii kandiddata geogr. Sciences, Rostov-na-Donu, Rostovskiy gosyniversitet, 299 p. (in Russian).

3. Egorov, V.N., Polikarpov, G.G. \& Osvas, I. [et al.], 2002, “Radiologicheskiy otklik Chernogo morya na Chernobylskuyu yadernuyu avariyu $v$ otnoshenii dolgozhivishchikh radionuklidov ${ }^{90} \mathrm{Sr} i{ }^{137} \mathrm{Ce}$ [Radiologic response of the Black Sea to the Chernobyl nuclear accident regarding the long-living radionuclides ${ }^{90} \mathrm{Sr}$ and $\left.{ }^{137} \mathrm{Ce}\right] ”$, Morskoy ekologicheskiy zhurnal, vol. 1, pp. 5-15 (in Russian).

4. Lisiysyn, A.P., 1978, "Protsessy okeanskoy sedimentatsii [Processes of oceanic sedimentation]”, Moscow, Nauka, 392 p. (in Russian).

5. Shnyukov, E.F., Ogorodnikov, V.I. \& Inozemtsev, Yu.Ya. [et al.], 2003, "Litologostratigraficheskaya kharakteristika donnykh otlozheniy krymskogo shelfa i glubokovodnoy chasti Chernogo morya [Lithologic-stratigraphic characteristic of bottom sediments of the Crimea shelf and the Black Sea deep-water part]”, Geologicheskiy zhurnal, vol. 1, pp. 9-23 (in Russian).

6. Ovsyany, E.I., Kotel'yanets, E.A. \& Orekhova, N.A., 2009, “Mysh'yak i tyazhelye metally v donnykh otlozheniyakh Balaklavskoy bukhty (Chernoe more) [Arsenic and heavy metals in the bottom sediments of the Balaklava Bay (the Black Sea)]”, Morskoy gidrofizicheskiy zhurnal, vol. 4, pp. 67-80 (in Russian).

7. Fomin, V.V., Ivanov, V.A., 2005, “Modelirovanie volnovykh techeniy i transporta nanosov v ghibrezhnoy zone Evpatorii [Modeling of wave currents and alluvium transport in the coasta zone of Evpatoria]", Ekologicheskaya bezopasnost' pribrezhnoy i shelfovoy zon i kompleksnoe ispol'zovanie resursov shelfa, vol. 13, pp. 211-228 (in Russian). 
8. Moiseenko, O.G., Orekhova, N.A., 2011, "Issledovanie mekhanizma mnogoletney evolutsii tsikla ugleroda $v$ ecosisteme Sevastopolskoy bukhty [Investigation of a mechanism of longterm evolution of a carbon cycle in the Sevastopol bay ecosystem]", Morskoy gidrofizicheskiy zhurnal, vol. 2, pp. 72-83 (in Russian).

9. Kubryakov, A.I., Popov, M.A., 2005, "Modelirovanie tsirkulyatsii i rasprostraneniya zagryaznyayushchey primesi $v$ Balaklavskoy bukhte [Modeling of circulation and propagation of contaminating impurities in the Balaklava Bay]”, Morskoy gidrofizicheskiy zhurnal, vol. 3, pp. 49-61 (in Russian).

10. Popov, M.A., 2006, "Geomorfologicheskiy ocherk zaliva Megalo-Yalo i Balaklavskoy bukhty [Geomorphiligical description of the Megalo-Yalo Gulf and the Balaklava Bay]”, Ekologicheskaya bezopasnost' pribrezhnoy i shelfovoy zon i kompleksnoe ispol'zovanie resursov shelfa, vol. 14, pp. 209-214 (in Russian).

11. Lomakin, P.D., 2011, “Okeanologicheskaya kharakteristika i otsenka zagryazneniya vod Balaklavskoy bukhty [Oceanological characteristic and evaluation of the Balaklava Bay water pollution]”, Sevastopol, ECOSI-Gidrofizika, 184 p. (in Russuan).

12. Repetin, L.N., Belokopytov, V.N. \& Lipchenko, M.M., 2003, “Vetry i volnenie v pribrezhnoy zone yugo-zapadnoy chasti Kryma [Winds and waves in the coastal zone of the Crimea southwestern part]”, Ekologicheskaya bezopasnost' pribrezhnoy i shelfovoy zon i kompleksnoe ispol'zovanie resursov shelfa, vol. 8, pp. 13-28 (in Russian).

13. Popov, M.A., Kovrigina, N.P. \& Lisitskaya, E.V., 2008, “Monitoring vod Balaklavskoy bykhty [Monitoring of the Balaklava Bay waters]”, Trudy YUGNIRO, vol. 46, pp. 118-124 (in Russian).

14. Kuftarkova, E.A., Kovrigina, N.P. \& Rodionova, N.Yu., 1999, “Gidrokhimicheckaya kharakteristika bod Balaklavskoy bukhty $i$ prilegayushchey $k$ ney pribrezhnoy chasti Chernogo morya [Gydrochemical characteristics of the Balaklava Bay waters and the adjoining coastal part of the Black Sea]”, Gidrobiologicheskiy zhurnal, vol. 35, no 3, pp. 88-99 (in Russian).

15. Popov, M.A., Chepyzhenko, A.I. \& Eremin, I.Yu., 2005, “Opredelenie kontsentratsiy i prostranstvennogo raspredeleniya zagryaznyayusgchikh veshchestv Balaklavskoy bukhty gidroopticheskimi metodami $v$ osenniy period [Determination of the contaminants' concentrations and spatial distribution in the Balaklava Bay by the hydro-optical methods in autumn period]", Ekologicheskaya bezopasnost' pribrezhnoy i shelfovoy zon i kompleksnoe ispol'zovanie resursov shelfa, vol. 12, pp. 202-207 (in Russian).

16. 1937, “Lotsiya Chernogo morya [Sailing directions of the Black Sea]”, Leningrad, Gidrograficheskiy otdel UMS PKKA, 482 p. (in Russian).

17. 1980, “GOST 17.1.5.01-80. Obshchie trebovaniya $k$ otboru prob donnykh otlozheniy vodnykh objektov dlya analiza na zagryaznennost [General requirements to sediment sampling in water basins for pollution analysis]”, Moscow, Gosudarstvenny komitet SSSR po standartam, 5 p. (in Russian).

18. 1979, "GOST 12536-79. Metody laboratornogo opredeleniya granulometricheskogo (zernovogo) i mikroagregatnogo sostava [Methods of laboratory determination of granulometric (discrete) and micro-aggregate compositions]”, Moscow, Gosudarstvenny komitet SSSR po delam stroitel'stva, 20 p. (in Russian).

19. 2002, "EDSTU ISO 10693-2001. Kachestvo grunta. Opredelenie soderzhaniya karbonatov. Obyemny metod (ISO 10693:1995, IDT) [Ground quality. Determination of carbonate content. Volumetric method (ISO 10693:1995, IDT)]”, Kiev, Derzhspozhivstandart Ukrainy, 7 p. (in Russian).

20. 2007, DSTU ISO 14235-2005. Kachestvo grunta. Opredelenie organicheskogo ugleroda sulfokhromnym okisleniem (ISO 14235:1998, IDT) [Ground quality. Determination of organic carbon by the chromic-sulfuric oxidation (ISO 14235:1998, IDT)]”, Kiev, Derzhspozhivstandart Ukrainy, 10 p. (in Russian).

21. 1985, “Geologiya shelfa USSR. Litologiya [Geology of Ukr.SSR shelf]”, Kiev, Naukova dumka, 192 p. (in Russian). 